\title{
Experimental study of polymer-based scaffolds promoting bone tissue repair in oroantral communication
}

\author{
Andrey I. Yaremenko ${ }^{1}$, Anna V. Lysenko ${ }^{1}$, Elizaveta A. Ivanova ${ }^{1}$, Galina U. Ukina ${ }^{4}$, Alexander D. Vilesov ${ }^{3}$, \\ Marina A. Chibisova ${ }^{5}$, Anna A. Zubareva ${ }^{2}$, Oleg V. Galibin ${ }^{3}$ \\ ${ }^{1}$ Department of Maxillofacial Surgery, Pavlov University, St. Petersburg, Russia \\ ${ }^{2}$ Department of Otorhinolaryngology, Pavlov University, St. Petersburg, Russia \\ ${ }^{3}$ Raisa Gorbacheva Memorial Research Institute of Pediatric Oncology, Hematology and Transplantation, St. Petersburg, Russia \\ ${ }^{4}$ Research Center, Pavlov University, St. Petersburg, Russia \\ ${ }^{5}$ Saint Petersburg Stomatology Institute of Postgraduate Education, St. Petersburg, Russia
}

\author{
Dr. Elizaveta A. Ivanova, Department of Maxillofacial \\ Surgery, Pavlov University, L. Tolstoy St 6-8, 197022, \\ St. Petersburg, Russia
}

Phone: +7 (953) 1441508

E-mail: lizabet159@yandex.ru

Citation: Yaremenko AI, Lysenko AV, Ivanova EA et al. Experimental study of polymer-based scaffolds promoting bone tissue repair in oroantral communication. Cell Ther Transplant 2019; 8(4): 77-83.

\section{Summary}

Odontogenic maxillary sinusitis (OMS) takes one of the leading position among the paranasal sinus diseases. According to current reviews, the number of patients with OMS is increasing every year, and makes up from 4 to $7 \%$ of the maxillofacial diseases. Recently, a perforating form of OMS becomes more common in practice of maxillofacial surgery. Perforative sinusitis occurs due to break of mucoperiosteum in response to some pathological conditions, most frequently, following extraction of a superior tooth. Therefore, improvement of existing approaches and development of new affordable and less traumatic methods for treatment of sinusitis remains quite relevant. Over last years, usage of polymer materials (both natural and artificial products) has become increasingly popular in maxillofacial and dental surgery. Such materials should have several favorable properties: lack of cytotoxicity, biocompatibility, resorbability and good handling characteristics. The synthetic polymer polycaprolactone (PCL) meets these requirements to a greater extent. Due to its three-dimensional porous structure, these polymers are actively used in tissue engineering. Available data on the opportunity of bone tissue regeneration by the polymer structures suggest that they can be used to stimulate osteogenesis and maintain the height of the alveolar process of the upper jaw in cases of oroantral communication (OAC) occurring after tooth extraction. Of note, PCL is a safe material ap- proved by the FDA for use in drug delivery devices and implantation scaffolds. Considering these data, it is of great interest to evaluate the opportunity of its application in the sites of inflammation, e.c., for elimination of OAC defect in presence of developing sinusitis. The aim of our study was to evaluate the opportunity of using a PCL matrix in order to close the OAC using an in vivo experimental model.

\section{Materials and methods}

In an experimental study, xenogeneic transplantation of polycaprolactone matrix was performed into the lower wall of maxillary sinus after the OAC development in rabbits. Nine animals were sacrificed after 4,8 and 24 weeks. The maxillary bones were dissected, cut into smaller blocks, and the specimens were immediately placed in formalin. Serial sections were stained and examined using light microscope.

\section{Results}

The morphological study showed that there are early signs of connective tissue ingrowth to the matrix mesh 1 month after implantation. The surrounding capsule was thin and showed minimal signs of inflammation, which completely disappeared by the second month after the intervention. Over the next 4 months, the capsule becomes thinner, the matrix was totally penetrated by connective tissue and blood vessels. It helped to retain the height of alveolar process in the upper jaw at the site 
of tooth extraction. In conclusion, the proposed method for OAC closure by means of the PCL scaffold system can retain the space of the lost maxillary bone fragment for up to 6 months being able to stimulate osteogenesis, as shown by our animal experiments.

\section{Keywords}

Oroantral communication, maxillary sinus, polycaprolactone, polymer scaffolds, bone regeneration.

\section{Introduction}

Maxillary sinusitis is one of the most common diseases of paranasal sinuses [1]. According to latest statistics, the prevalence of sinusitis in Russia is growing to 1.420 cases per 100.000 adult population [2]. Odontogenic maxillary sinusitis, comprises 4 to $7 \%$ of all cases of this morbidity, and its incidence also continues to grow [3]. Oroantral communication (OAC) takes a sufficient place in pathogenesis of odontogenic sinusitis [4]. OAC occurs most often when the upper molars are removed, and the frequency of such forms of sinusitis is $41-92 \%$ [5].

Bone tissue regeneration in the area of OAC defect can be achieved not only by structural replacement of such defect, but also by stimulating the regeneration of surrounding bony tissues [6]. To this purpose, biocompatible polymer scaffolds can be used [7]. Appropriate matrices or scaffold systems represent an artificial tissue equivalent with three-dimensional structure that form a substrate for the tissue regeneration [8]. An ideal scaffold should promote tissue restoration, being, however, resorbed afterwards. Moreover, the scaffold should have a pore size optimal for uniform cell distribution, an adhesive surface that promotes cell proliferation and differentiation, and be biocompatible [9].

Synthetic and natural polymer matrices are discerned. According to several authors, synthetic fibrous matrices are the most promising for bone tissue regeneration [10]. The matrices obtained by electrospinning method are of greatest interest. It allows to produce matrices with specified structural and biomechanical properties. The scaffold systems made with this technique have good elasticity and mechanical strength [11]. Polycaprolactone nonwoven fabric is most often used in electrospinning technology. The results of experimental studies indicate to successful use of polycaprolactone-based matrices for replacement of skin and bone defects [12].

The 3D porous scaffolds can maintain the physical space necessary for bone regeneration, thus preventing invasion of undesired cells, along with anchoring endogenous osteogenic cells, in order to induce cell ingrowth and promoting molecular microenvironment for osteoblastic differentiation [13]. Due to its biodegradability and biocompatibility, PCL can be employed as a bone substitute to reconstruct the alveolar bone in the oral cavity. In addition, PCL is a safe material approved by the FDA for use in drug delivery devices and implantation scaffolds [14]. Proven biocompatibility and optimal physico-chemical characteristics make it possible to use PCL as a matrix for closing the OAC defect [15].

The aim of our study was to test potential effects of PCLbased matrices upon closure of oroantral defect in experi- mental animals. The results show effective in vivo regeneration of maxillar bone with the local PCL implants.

\section{Materials and methods}

We have performed an in vivo experimental study to assess the opportunity of OAC treatment by means of PCL-based scaffold systems. The study was carried out at the Research Center of First St. Petersburg State I. Pavlov Medical University. The polycaprolactone matrices were manufactured at the Tomsk Polytechnic University using the electrospinning technique (Fig. 1).

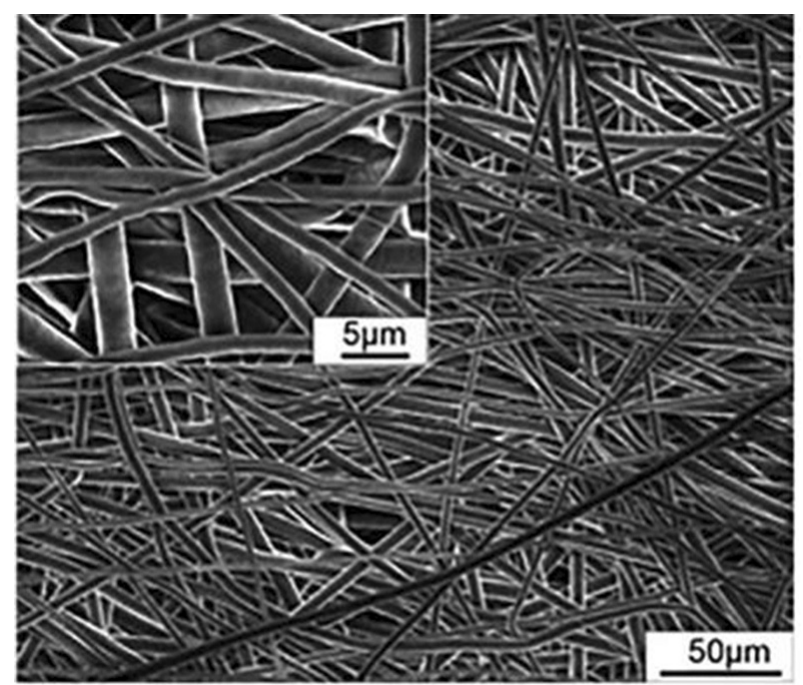

Figure 1. Micrograph. 200x magnification. Cross section of spongy cylindrical matrix samples based on polycaprolactone

To prepare pure polycaprolactone-based scaffolds, the polymer was dissolved in chloroform at a concentration of $9 \%$ and $6 \%$. A syringe pump was used to supply solutions through an extension tube covered with blunt 21 gauge needles (inner diameter $0.51 \mathrm{~mm}$ ). A voltage of $6.5 \mathrm{kV}$ was applied using a high voltage power source. During the electrospinning process, a special collector needle $(8 \mathrm{~cm})$ was used, with a deposition time of $60 \mathrm{~min}$ and a fixed injection rate of $1.5 \mathrm{~mL} / \mathrm{h}$. The prepared samples were separated from the collector and used for further experiments. The square-shaped specimens $(5 \times 5 \mathrm{~mm})$ were produced, then being sterilized and placed into a sterile medium (Fig. 2).

The male rabbits were used (Soviet Chinchilla) at the age of 1 year, weighing from $3 \mathrm{~kg}$. A total of 9 laboratory animals were used in the study. Surgery was made under general anesthesia with using ketamine. The experimental animals were subject to extraction of the right anterior chewing tooth 


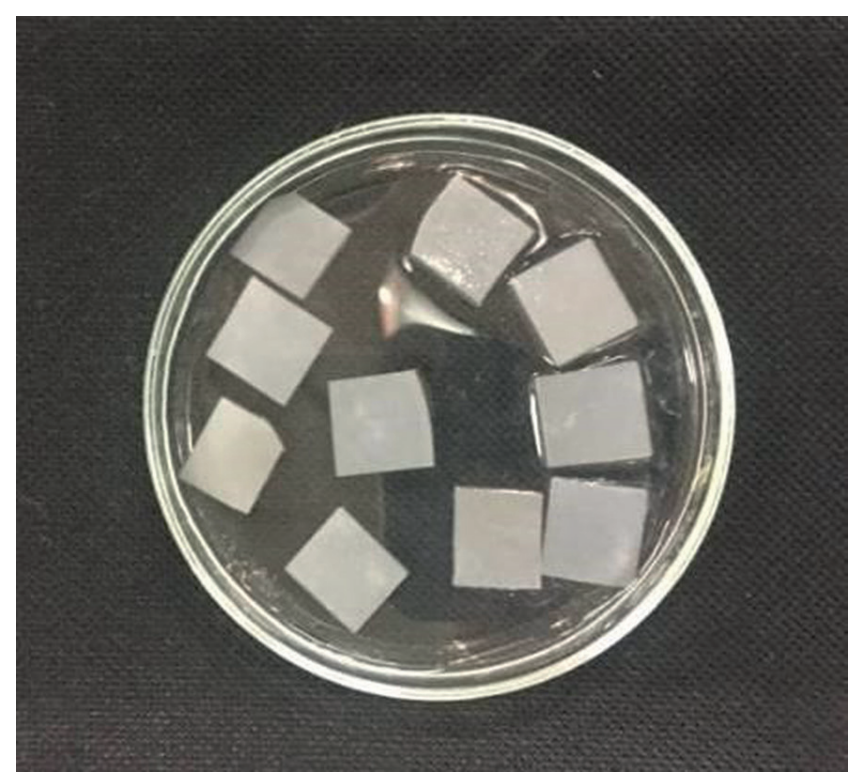

Figure 2. Polycaprolactone Scaffold Samples

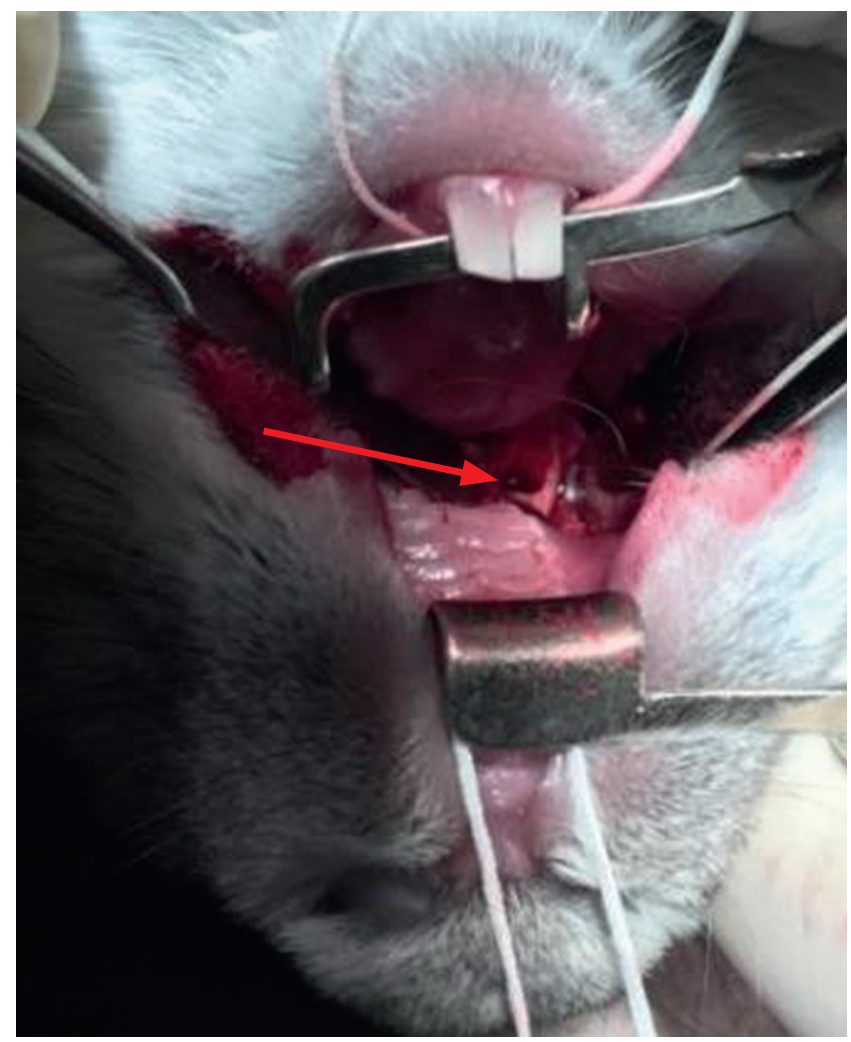

Figure 3. The experimental animal after the extraction of the anterior masticatory tooth (the hole is marked with an arrow)

using surgical forceps (Fig. 3). Thereafter, a hole was penetrated with a metal probe to the lumen of the maxillary sinus, thereby establishing an OAC condition. A matrix of polycaprolactone was introduced into the hole of the extracted tooth. Upon perforation, the matrix was impregnated with blood, but it did not change its volume. Therefore, additional fixation of the matrix was carried out using two metal pins to the edges of the defect (Fig. 4). The wound was sutured tightly with overlapping of the defect area with a mucoperiosteal flap.

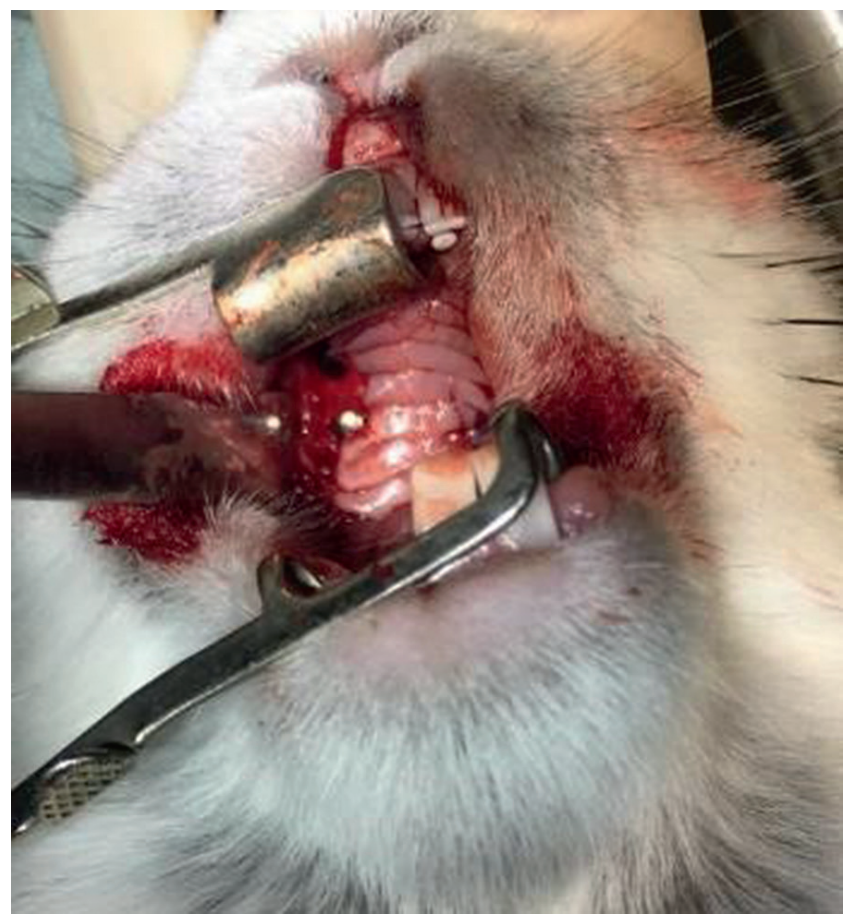

Figure 4. The matrix of polycaprolactone is fixed in the area of the hole of the extracted tooth with two pins

The animals were sacrificed from the experiment according to the schedule at the following observation terms: 1 month, 2 months, and 6 months after surgery. The rabbits were anaesthesized, decapitated, and a fragment of the upper jaw $2 \times 2 \mathrm{~cm}$ was separated using a drill, $1 \mathrm{~cm}$ around the site of matrix installation, while maintaining the oral mucosa. The preparations were fixed in formalin, decalcified, and embedded into paraffin blocks. Then, $5 \mu \mathrm{m}$-thick sections were sliced, that were stained with hematoxylin and eosin (H\&E), and a histochemical reaction for connective tissue elements was performed with Mallory staining using the BioVitrum kit (Russia). The photos were obtained with Leica DM750 microscope (Germany) using a $10 \times 10$ eyepiece, $40 \times$ lenses, and the ICC50 digital camera (Leica, Germany).

\section{Results}

One month after implantation, a connective tissue capsule is detected around the matrix (Fig. 5). The cellular composition of the matrix is represented mainly by fibroblasts, macrophages and a small number of leukocytes. Giant multinuclear cells are located on the matrix fibers. Between the fibers are seen macrophages and fibroblasts, which actively synthesize collagen fibers. Hence, the experimental area was completely penetrated by thin collagen fibers within 1 month. No signs of inflammatory cellular response were detectable on affected bone fragment (Fig. 6), thus resulting into growth of connective tissue which sprouted into the matrix, along with single blood vessels and multinuclear giant cells of foreign bodies in small amounts (Fig. 7).

At two months of observation, there were no signs of inflammatory reaction in the capsule surrounding the matrix. $\mathrm{Mu}$ cosa lining the maxillary sinus and at the root of the tooth was immediately adjacent to the matrix (Fig. 8). The severity 


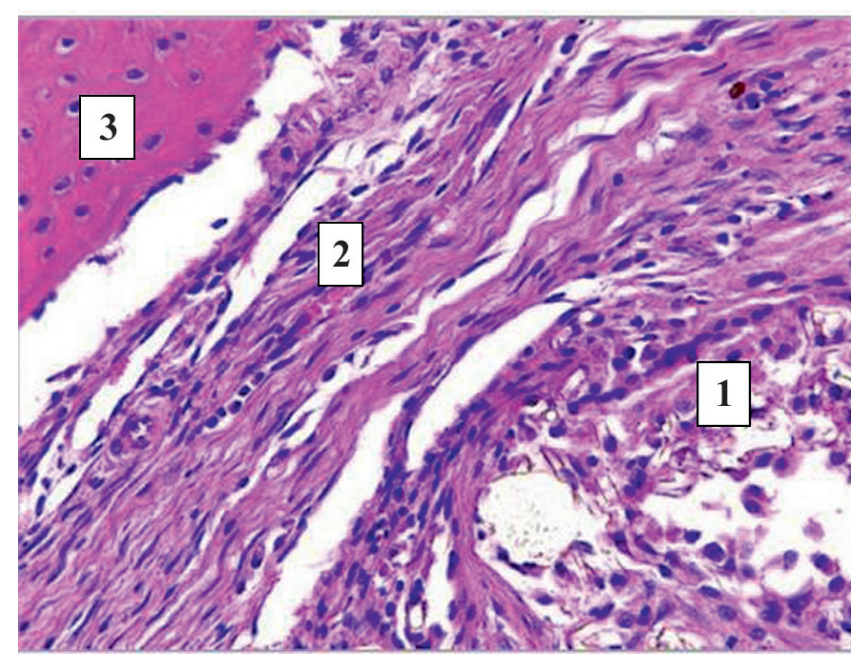

Figure 5. 400x magnification. The capsule surrounding the polycaprolactone matrix 1 month after implantation. H\&E staining

1 - matrix, 2 - connective tissue capsule surrounding the matrix, 3 - bone wall of the tooth alveole.

degree of matrix sprouting by connective tissue elements has become significantly greater over this time. In addition to fibroblasts, giant multinuclear cells of foreign bodies, and macrophages, a small number of leukocytes was visualized between the matrix fibers (Fig. 9). Neoangiogenesis and PCL matrix resorption were also in progress (Fig. 10).

After 6 months of our experiment, the matrix was completely penetrated by thick bundles of collagen fibers, whereas any sufficient signs of an inflammatory tissue reaction were not revealed in the implantation area. Bony wall of the tooth well was covered with osteoblasts and single osteoclasts (Fig. 11).

A significant decrease of polycaprolactone amounts was noted in the matrix volume by 6 months of experiment. This event may be caused by active destruction of the synthetic matrix fibers and indicates a high rate of its resorption. At the same time period, its structure was almost completely replaced by well-vascularized connective tissue (Fig. 12).

\section{Discussion and conclusion}

In an in vivo pilot study, there were no cases of PCL-scaffolds rejection. The matrix is flexible and durable, it was not loosening during fixation in the wound. However, it does not change its volume when contacting with blood, therefore, its additional on-site fixation is necessary to avoid synthetic matrix migration to the lumen of maxillary sinus.

According to the results of a morphological study, as soon as a month after implantation, there are signs of connective tissue penetration to the matrix structure. The surrounding capsule is thin and shows only minimal signs of inflammation, which completely disappeared by the $2^{\text {nd }}$ month after the intervention. Over next 4 months, the capsule becomes thinner, the matrix is totally penetrated by connective
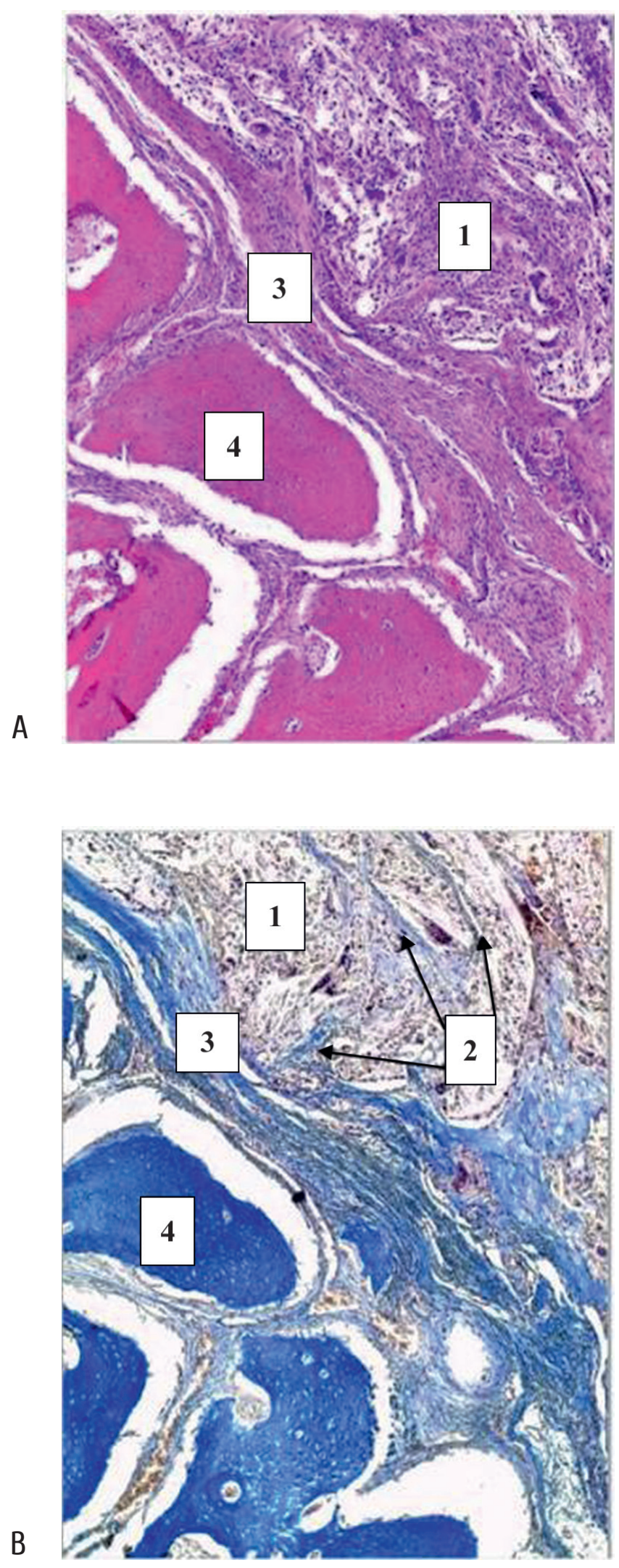

Figure 6. Micrograph. 100x magnification. Fragment of the maxilla of the rabbit 1 month after the installation of the matrix of polycaprolactone (A - H\&E staining, B - staining Mallory method)

1 - matrix, 2 - collagen fibers sprouting into the matrix, 3 connective tissue capsule surrounding the matrix, 4 - bone wall of the tooth alveole. 


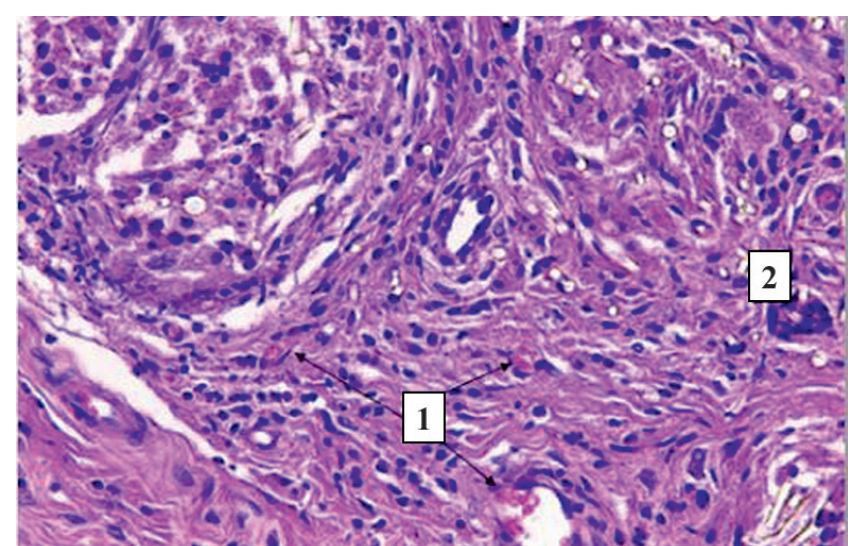

Figure 7. Micrograph. 400x magnification. Fragment of the maxilla of the rabbit 1 month after the installation of the matrix of polycaprolactone. H\&E staining

1 - blood vessels in the structure of the matrix, 2 - multinuclear giant cells.

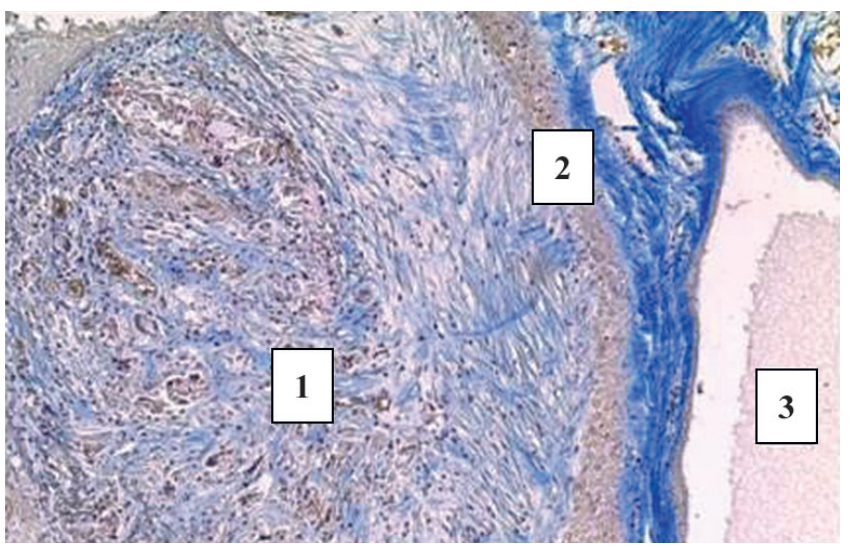

Figure 9. Micrograph. 100x magnification. Fragment of the maxilla of the rabbit 2 months after the installation of the matrix of polycaprolactone (stained by the method of Mallory)

1 - matrix penetrated by collagen fibers, 2 - connective tissue capsule surrounding the matrix, 3 - maxillary sinus lumen filled with mucus.

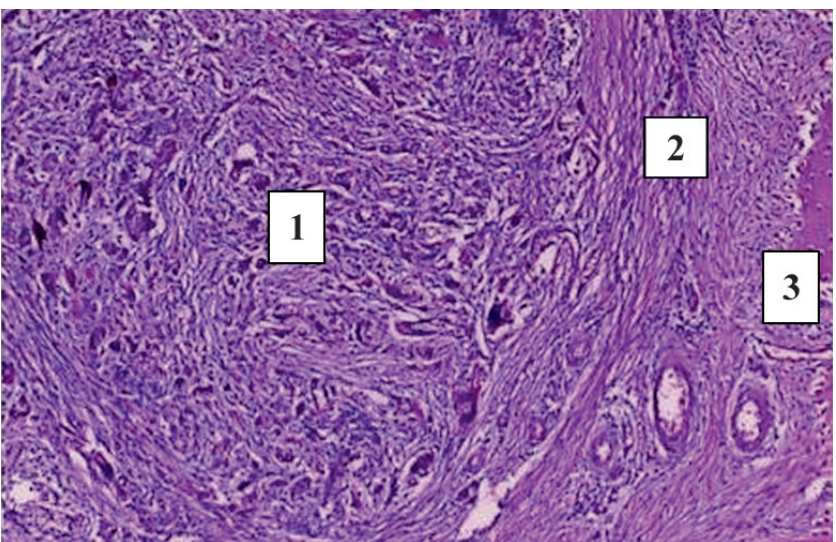

Figure 11. Micrograph. 100x magnification. Fragment of the maxilla of the rabbit 6 months after the installation of the matrix of polycaprolactone. H\&E staining

1 - matrix penetrated by collagen fibers, 2 - connective tissue capsule surrounding the matrix, 3 - bone wall of the tooth alveole.

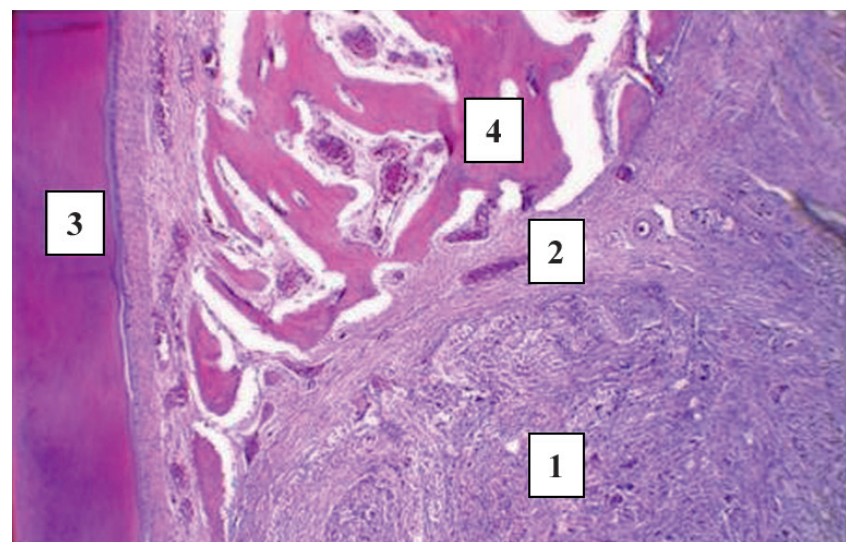

Figure 8. Micrograph. 40x magnification. Fragment of the maxilla of the rabbit 2 months after the installation of the matrix of polycaprolactone. H\&E staining

1 - matrix, 2 - connective tissue capsule surrounding the matrix, 3 - dentin of the tooth root, 4 - bone wall of the tooth alveole.

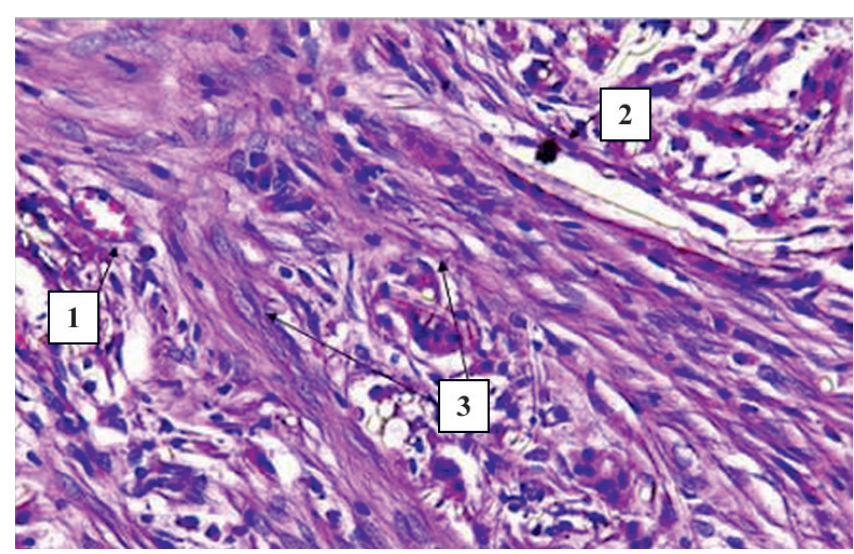

Figure 10. Micrograph. 400x magnification. Fragment of the maxilla of the rabbit 2 months after the installation of the matrix of polycaprolactone. H\&E staining 1 - blood vessels, 2 multinuclear giant cells, 3 - fibers of loose connective tissue.

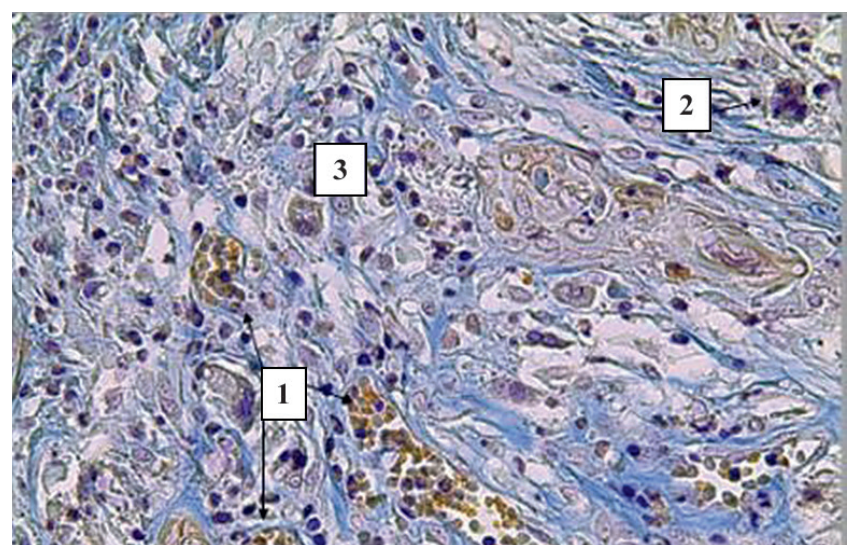

Figure 12. Micrograph. 400x magnification. Six months after installing the polycaprolactone matrix (stained by the method of Mallory)

1 - blood vessels, 2 - multinuclear giant cells, 3 - fibers of loose connective tissue. 
tissue and blood vessels. It helps to maintain the height of the alveolar process of the upper jaw at the site of the extracted tooth.

Other works also confirm good tolerability of PCL in various experimental settings $[16,17,18,19]$.

\section{Conclusion}

The scaffolds based on polycaprolactone are biocompatible, do not cause a pronounced inflammatory reaction in surrounding tissues and demonstrate a good potential for their use for closing the OAC lesions.

The proposed method for eliminating the oroantral communication using a scaffold system ensures volume maintenance of the deficient maxillary bone fragment for up to 6 months, and moreover, it may stimulate local osteogenesis, as shown in the animal model.

In the future, we plan to continue studies on the polymer constructs in order to repair OAC and to conduct a comparative in vivo experimental study of natural and synthetic bioengineered materials.

\section{References}

1. Yildirim TT, Güncü GN, Göksülük D, Tözüm MD, Colak M, Tözüm TF. The effect of demographic and disease variables on Schneiderian membrane thickness and appearance. Oral Surg Oral Med Oral Pathol. Oral Radiol.2017;124(6): 568-576.

2. Baydik OD, Sysolyatin PG, Gurin AA, Ilenok OV. Modern approaches to diagnostics and treatment of chronic odontogenic maxillary sinusitis. Russian Journal of Dentistry. 2015;19(4):14-18 (In Russian).

3. Little RE, Long CM, Loehrl TA, Poetker DM. Odontogenic sinusitis: A review of the current literature. Invest Otolaryngol. 2018; 3(2):110-114.

4. Troeltzsch M, Pache C. Etiology and clinical characteristics of symptomatic unilateral maxillary sinusitis: A review of 174 cases. J Cranio-Maxillofac Surg. 2015; 43(8):1522-1529.

5. Akhlaghi F, Esmaeelinejad M, Safai P. Etiologies and treatments of odontogenic maxillary sinusitis: A systematic review. Iran Red Crescent Med J. 2015;7(12): e25536.

6. Yakushiji N. Treatment for oroantral communications of 170 cases. Oral Maxillofac Surg. 2014; 72(9, Suppl): e82.

7. Dreifke MB, Ebraheim NA, Jayasuriya AC. Investigation of potential injectable polymeric biomaterials for bone regeneration. J Biomed Mater Res A. 2013; 101: 2436-2447.

8. Park SH, Park DS, Shin JW, Kang YG, Kim HK, Yoon TR, Shin JW. Scaffolds for bone tissue engineering fabricated from two different materials by the rapid prototyping technique: PCL versus PLGA. J Mater Sci Mater Med. 2012; 23:2671-2678.

9. Sheikh Z, Hamdan N, Ikeda Y, Grynpas M, Ganss B, Glogauer M. Natural graft tissues and synthetic biomaterials for periodontal and alveolar bone reconstructive applications: A review. Biomater. Res. 2017; 21: 9.

10. Williams JM, Adewunmi A, Schek RM, Flanagan CL, Krebsbach PH, Feinberg SE, Hollister SJ, Das S. Bone tissue engineering using polycaprolactone scaffolds fabricated via selective laser sintering. Biomaterials. 2005, 26:4817-4827.

11. Karimi A, Karbasi S, Razavi S, Zargar EN. Poly(hydroxybutyrate)/chitosan aligned electrospun scaffold as a novel substrate for nerve tissue engineering. Adv Biomed Res. 2018:7(1):44-50.

12. Kretlow JD, Klouda L, Mikos AG, Injectable matrices and scaffolds for drug delivery in tissue engineering. Adv Drug Deliv Rev. 2007;59: 263-273.

13. Mckee MD. Extracellular matrix and mineralization of craniofacial bone. In: Mineralized Tissues in Oral and Craniofacial Science: Biological Principle. 2012. J Wiley \& Sons Inc. Hoboken, NY, USA.

14. Yaremenko AI, Lysenko AV, Ivanova EA, Vilesov AD, Galibin OV, Petrov NL, Kirillov PA. Prospectives for using artificial scaffolds in oral and craniofacial surgery: literature review. Cell Ther Transplant. 2018;7;1(22): 20-26.

15. Ye P, Yu B, Deng J, She RF, Huang WL. Application of silk fibroin/chitosan/nano-hydroxyapatite composite scaffold in the repair of rabbit radial bone defect. Exp Ther Med. 2017;14;6: 5547-5553.

16. Islas-Arteaga NC, Rivera AR, Esquiliano Rendon DR, Morales-Corona J, Ontiveros-Nevares PG, Flores Sánchez MG, Mojica-Cardoso C, Olay R. Electrospun scaffolds with surfaces modified by plasma for regeneration of articular cartilage tissue: a pilot study in rabbit. Int J Polym Mater Polym Biomater. 2019;68:18:1089-1098.

17. Zheng P, Hu X, Lou Y, Tang K. A Rabbit Model of osteochondral regeneration using three-dimensional printed polycaprolactone-hydroxyapatite scaffolds coated with umbilical cord blood mesenchymal stem cells and chondrocytes. Med Sci Monit. 2019;25:7361-7369.

18. Liao W, Xu L, Wangrao K, Du Y, Xiong Q, Yao Y. 2019. Three-dimensional printing with biomaterials in craniofacial and dental tissue engineering. Peer J 7:e7271.

19. Yaremenko AI, Zubareva AA, Lysenko AV, Chibisova MA, Udin VE, Popriaduchin PV, Ukina GU, Ivanova EA. Application of chitosan matrix for closure maxillary sinus perforation: future prospects. Experimental work. The Dental Institute. 2017; 2 (75):62-63. 


\title{
| Экспериментальное изучение полимерных матриц, способствующих репарации костной ткани при ороантральном дефекте
}

\author{
Андрей И. Яременко ${ }^{1}$, Анна В. Лысенко ${ }^{1}$, Елизавета А. Иванова ${ }^{1}$, Александр Д. Вилесов ${ }^{3}$, Галина Ю. Юкина ${ }^{4}$, \\ Марина А. Чибисова ${ }^{5}$, Анна А. Зубарева ${ }^{2}$, Олег В. Галибин ${ }^{3}$ \\ ${ }^{1}$ Кафедра челюстно-лицевой хирургии, Первый Санкт-Петербургский государственный медицинский университет \\ им. акад. И. П. Павлова, Санкт-Петербург, Россия \\ ${ }^{2}$ Кафедра оториноларингологии, Первый Санкт-Петербургский государственный медицинский университет \\ им. акад. И. П. Павлова, Санкт-Петербург, Россия \\ ${ }^{3}$ НИИ детской онкологии, гематологии и трансплантологии им. Р. М. Горбачевой, Санкт-Петербург, Россия \\ ${ }^{4}$ Научно-исследовательский центр Первого Санкт-Петербургского государственного медицинского университета \\ им. акад. И. П. Павлова, Санкт-Петербург, Россия \\ ${ }^{5}$ Санкт-Петербургский стоматологический институт последипломного образования, Санкт-Петербург, Россия
}

\section{Резюме}

Одонтогенный максиллярный синусит (ОМС) занимает одно из первых мест по заболеваемости среди болезней параназального синуса. По современным обзорам, число пациентов с ОМС возрастает каждый год и составляет 4-7\% всех заболеваний верхней челюсти. В настоящее время в практике челюстно-лицевой хирургии все чаще встречается перфоративная форма ОМС. Перфоративный синусит возникает из-за разрушения периоста при некоторых патологических состояниях, наиболее часто после экстракции верхнего зуба. Поэтому улучшение существующих подходов и разработка новых доступных и менее травматичных методов лечения синусита пока остается актуальным. В течение последних лет применение полимерных материалов (как естественных, так и синтетических продуктов) стало весьма популярным в челюстно-лицевой хирургии. Такие материалы должны иметь ряд существенных преимуществ: отсутствие цитотоксичности, биосовместимость, резорбируемость и возможность удобной обработки. Синтетический полимер поликапролактон (ПКЛ) соответствует этим требованиям в большой мере. Благодаря своей трехмерной пористой структуре, эти полимеры активно применяются в тканевой инженерии. Имеющиеся данные о возможности регенерации костной ткани в полимерных структурах предполагают, что они могут быть использованы для стимуляции остеогенеза и поддерживать высоту альвеолярного отростка верхней челюсти в случаях ороантральной коммуникации (ОАК), возникающей после удаления зуба. Следует отметить, что полимер ПКЛ безопасный материал, одобренный FDA (США) для применения в устройствах для доставки препаратов и основ-скаффолдов для имплантации. С учетом этих данных, представляет большой интерес оценка их использования в зонах воспаления, например, для устранения дефекта при ОАК при развитии синусита. Целью нашего исследования была оценка возможности применения матриц ПКЛ для закрытия дефекта ОАК, в экспериментальной модели in vivo. В данном экспериментальном исследовании, проводилась ксеногенная трансплантация поликапролактонового матрикса в нижнюю стенку максиллярного синуса после развития ОАК у кроликов. Девять животных исследовали в сроки 4,8 и 24 недели. Проводили рассечение костей верхней челюсти, резали на меньшие блоки и помещали образцы в формалин. Серийные гистологические препараты окрашивали и исследовали методами световой микроскопии. Морфологический анализ показал, наличие ранних признаков врастания соединительной ткани в сетку матрикса уже через 1 мес. после ее имплантации. Окружающая капсула была тонкой, с минимальными признаками воспаления, которое полностью исчезало к 2 мес. после вмешательства. В течение последующих 4 мес. капсула становилась тоньше, синтетический матрикс полностью прорастал соединительной тканью и кровеносными сосудами. Это помогало сохранить высоту альвеолярного отростка верхней челюсти в месте экстракции зуба.

\section{Выводы}

Предложенный метод закрытия ороантральной коммуникации с применением системы ПКЛ-скаффолда может сохранить объем утраченного костного фрагмента на срок до 6 мес. и может стимулировать остеогенез, как показано нашими экспериментами на животных.

\section{Ключевые слова}

Ороантральная коммуникация, максиллярный синус, поликапролактон, полимерные матрицы, костная регенерация. 